\title{
Analisis dan Optimalisasi Potensi Lahan Pertanian sebagai Kajian Dampak Positif Erupsi Gunungapi Kelud 2014
}

\author{
Syamsul Bachri, Sugeng Utaya, Farizki Dwitri Nurdiansyah, Alif Erfika Nurjanah, Lela Wahyu Ning Tyas, \\ Denny Setia Purnama, dan Akhmad Amri Adillah
}

Jurusan Geografi, Universitas Negeri Malang, Malang Indonesia

Email koresponden: syamsul.bachri.fis@um.ac.id

Diterima : Juni 2017 ; Direvisi : Juli 2017; Dipubikasikan: September 2017

(c) 2017 Fakultas Geografi UGM dan Ikatan Geograf Indonesia.

\begin{abstract}
Abstrak Erupsi gunungapi Kelud pada tahun 2014 membawa dampak yang beragam terhadap kondisi pertanian di sekitarnya. Selain dampak negatif, erupsi gunungapi Kelud membawa dampak positif khususnya pada potensi lahan terdampak yang perlu dioptimalkan. Melalui penelitian ini, kajian optimalisasi potensi lahan terdampak erupsi dilakukan dengan beberapa tahapan. Tahap pertama berupa analisis kesesuaian lahan melalui penilaian multikriteria dan teknologi Sistem Informasi geografis (SIG). Selain kajian fisik, kegiatan Focus Group Discussion (FGD) merupakan tahapan kedua yang dilakukan untuk mengetahui bagaimana persepsi masyarakat terkait dengan dampak erupsi Gunungapi Kelud. Hasil penelitian menghasilkan peta kesesuaian dengan kelas kesesuaian S1 (64,74\%), S2 (31,51\%), S3 (3,75\%). Berdasarkan hasil pemetaan ini, sebagian besar wilayah Gunungapi Kelud berpotensi untuk pengembangan pertanian. Hal ini didukung dengan persepsi masyarakat kawasan Gunungapi Kelud yang berpendapat bahwa dampak positif erupsi dirasakan secara signifikan.
\end{abstract}

Kata kunci: Gunungapi Kelud, dampak positif, kesesuaian lahan

\begin{abstract}
Abstrac T.The 2014 eruption of Kelud Volcano has brought various effects on the surrounding agriculture. Aside from negative impact, it affected the potentials of agricultural land positively. This research analyzed the optimization of eruption-affected land using several steps. The first step was land suitability analysis with multicriteria assessment and Geographic Information System (GIS) technology. In addition to the physical analysis, Focus Group Discussion (FGD) was performed in the second step to identify the community's perception of the eruption impact. The research produced land suitability maps consisting of the following classification: S1 (64.74\%), S2 (31.51\%), and S3 (3.75\%). The maps revealed that the majority of the land in Kelud Volcano had the potentials for agricultural development. These findings were supported by the perception of the local community, which argued that they could significantly benefit from the positive impact of the eruption.
\end{abstract}

Keywords: Kelud Volcano, Positive Impact, Land Suitability

\section{PENDAHULUAN}

Erupsi Gunungapi Kelud pada 14 Februari 2014 membawa dampak yang signifikan terhadap kondisi lahan pertanian di sekitarnya. Material vulkanik yang dilontarkan sebesar 200 x 106 m3 (Blake and GNS Science (N.Z.), 2015). Dampak dari fenomena tersebut adalah tertutupnya lahan pertanian oleh material erupsi pada kawasan di sekitar Gunungapi Kelud. Fenomena erupsi gunungapi dapat membawa pengaruh negatif dan/atau positif pada kawasan terdampak (Bachri et al., 2015; Purnamasari dkk., 2015; Himayah dkk., 2017). Dalam jangka pendek tutupan material erupsi pada lahan pertanian memiliki dampak negatif. Namun demikian, dalam jangka panjang tutupan material erupsi pada lahan pertanian memiliki sisi positif, terutama dalam meningkatkan kesuburan dan daya dukung tanah terhadap terhadap aktivitas pertanian (Achmad dan Hadi, 2015).
Lahan yang terdapat pada kawasan terdampak erupsi gunungapi memiliki potensi untuk mendukung aktivitas pertanian. Kondisi lahan di kawasan gunungapi memiliki tingkat kesuburan tanah yang tinggi (Eswaran et al., 1993; Dahlgren et al., 2004). Menurut Shoji dan Takahashi (2002) material vulkanik hasil erupsi merupakan bahan yang memiliki kandungan unsur hara yang tinggi, sehingga menjadi sumber utama dalam mendukung peningkatan kesuburan dan daya dukung tanah. Peningkatan daya dukung lahan yang diakibatkan oleh kandungan senyawa kimia yang terdapat di dalam material erupsi. Material hasil erupsi memiliki kandungan senyawa kimia dengan komposisi total unsur tertinggi yaitu $\mathrm{Ca}, \mathrm{Na}, \mathrm{K}$ dan $\mathrm{Mg}$, sedangkan unsur makro lainnya berupa $\mathrm{P}$ dan $\mathrm{S}$, serta unsur mikro yang terdiri dari $\mathrm{Fe}, \mathrm{Mn}, \mathrm{Zn}$ dan $\mathrm{Cu}$. Senyawa-senyawa tersebut baik untuk pertumbuhan tanaman (Afandi et al., 2017). Upaya optimalisasi dan analisis lahan perlu 
dilakukan agar potensi pada lahan terdampak erupsi dapat dimanfaatkan dengan baik.

Optimalisasi potensi lahan di kawasan terdampak erupsi Gunungapi Kelud pada penelitian ini dilakukan dengan tahapan awal berupa analisis kesesuaian lahan. Upaya identifikasi kesesuaian lahan bertujuan untuk mengetahui penatagunaan lahan pertanian yang tepat untuk waktu mendatang (Collins et al., 2001), sehingga mendorong produktifitas hasil pertanian yang optimal (Ebrahim and Mohamed, 2017). Upaya identifikasi kesesuaian lahan dilakukan melalui 1) penilaian multikriteria melalui penerapan metode Analytical Hierarchy Process (AHP) yang diintegrasikan dengan teknologi Sistem Informasi Geografis (SIG), 2) analisis laboratorium dilakukan untuk mengetahui sifat fisik dan kimia tanah, 3) serta wawancara mendalam kepada masyarakat di kawasan penelitian. Penerapan metode AHP dalam analisis kesesuain lahan untuk pertanian telah dilakukan oleh beberapa peneliti seperti Thapa and Murayama (2008), Akınc1 et al., (2013), dan Feizizadeh and Blaschke (2013). Integrasi SIG pada analisis kesesuaian lahan bertujuan untuk menyimpan, memanajemen data dan memvisualisasikan data dalam bentuk informasi spasial (Kalogirou, 2002; Malczewski, 2004; Reshmidevi et al., 2009). Analisis sifat fisik dan kimia tanah digunakan untuk mengetahui kualitas dari masing-masing lahan di kawasan penelitian. Tahapan wawancara dilakukan untuk mendapatkan informasi mengenai persepsi masyarakat terkait dengan dampak erupsi Gunungapi Kelud terhadap kondisi pertanian saat ini.

Melalui 3 tahapan tersebut diharapkan analisis optimalisasi lahan dapat bersifat komprehensif yang melibatkan melibatkan beberapa disiplin ilmu seperti ilmu tanah, ilmu sosial, meteorologi hingga ilmu manajemen (Prakash, 2003). Kombinasi dan analisis berbagai jenis datanya dilakukan dengan integrasi penilaian multikriteria dan teknologi SIG (Feizizadeh and Blaschke, 2013). Penentuan kriteria parameter yang digunakan, penyusunan masing-masing kriteria ke dalam sistem hierarki, penentuan nilai bobot berdasarkan preferensi ahli, dan visualisasi informasi spasial, merupakan beberapa tahapan yang dilakukan dalam upaya penentuan kesesuaian lahan. Proses analisis tersebut dilakukan untuk mendukung upaya perencanaan dan manajemen penggunaan lahan pertanian (Ceballos-Silva and López-Blanco, 2003; Malczewski, 1999; 2004), khususnya di kawasan lahan bekas terdampak erupsi Gunungapi Kelud tahun 2014.

\section{Lokasi Penelitian}

Lokasi penelitian mengambil studi kasus pada lereng bagian barat daya dari Gunungapi Kelud (Gambar 1). Secara administratif, pada lokasi penelitian terdapat 47 desa dan 3 kecamatan, yang berada di Kabupaten Blitar dan Kediri. Tingkat elevasi pada lokasi penelitian antara 212-1.393 mdpl. Lokasi penelitian berada di Kawasan Rawan Bencana (KRB) zona-1 dan zona-2. Lokasi penelitian memiliki radius antara $10-20 \mathrm{~km}$ dari pusat Gunungapi Kelud. Material erupsi didominasi oleh abu vulkanik, dengan ukuran besar butiran $\leq 2 \mathrm{~cm}$ (Wardhana dkk., 2014).

Unit analisis kesesuaian lahan penelitian ini menggunakan bentuklahan yang terdapat di lokasi penelitian. Identifikasi kenampakan morfologi, morfogenesis, morfokronologi dan morfoaransemen dilakukan dalam membuat bentuklahan.

\section{METODE PENELITIAN}

\section{Penilaian Multikriteria}

Analisis kesesuaian lahan menggunakan berbagai integrasi informasi yang diturunkan dari berbagai sumber. Integrasi informasi tersebut dilakukan dengan penerapan penilaian multikriteria. Penerapan penilaian multikriteria bertujuan untuk membantu pengambilan keputusan yang tepat, merepresentasikan kriteria-kriteria yang menjadi input dalam penelitian (Feizizadeh and Blaschke, 2013). Pemberian nilai bobot pada masing-masing kriteria dapat dilakukan dengan penerapan penilaian multikriteria (Al-Mashreki et al., 2011). Nilai bobot yang dihasilkan merepresentasikan pengaruh masing-masing kriteria dalam analisis kesesuaian lahan untuk pertanian di lokasi penelitian.

\section{Pemilihan Kriteria Evaluasi Kesesuaian Lahan}

Sistem hierarki digunakan untuk menentukan kriteria-kriteria yang digunakan dalam penelitian. Malczewski (1999) menyatakan terdapat hubungan hierarki antara objectives dengan attribute yang digunakan. Penentuan kriteria yang digunakan dilakukan dengan terlebih dahulu dilakukan studi literatur, sehingga kriteria-kriteria tersebut memiliki pengaruh dan hubungan dengan tujuan penelitian. Penyusunan sistem hierarki dilakukan secara iteratif (Gambar 2). 


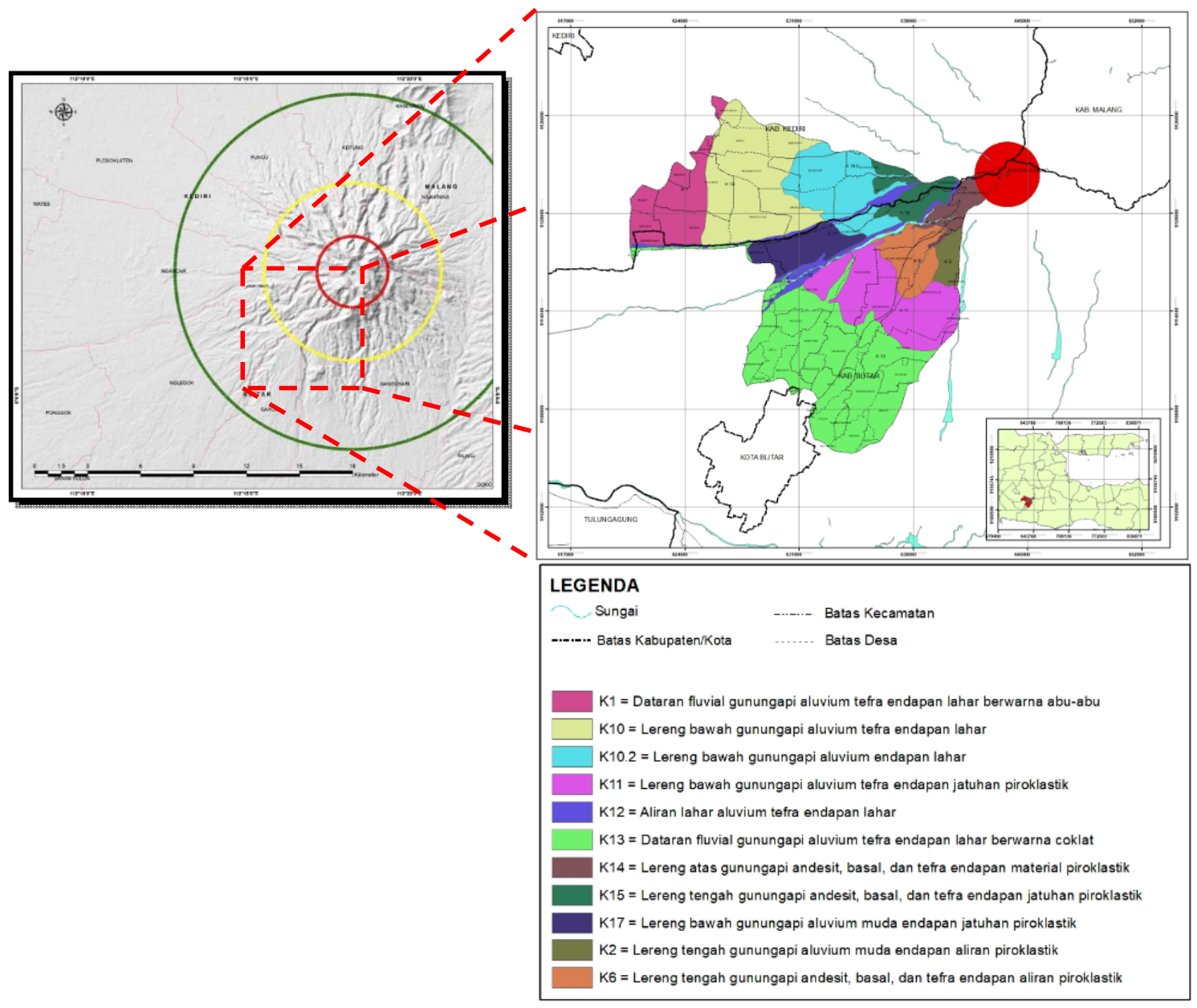

Gambar 1. Lokasi Penelitian



Gambar 2. Bagan Penyusunan Sistem Hierarki Dilakukan Secara Iteratif (Prakash, 2003) 


\section{Pengambilan dan Persiapan Data Menggunakan SIG}

Langkah pertama yang dilakukan dalam analisis kesesuaian lahan pada penelitian ini adalah persiapan data sebagai dasar penelitian dan pembuatan peta bentuklahan sebagai acuan pengambilan sampel tanah. Kemudian dilakukan evaluasi menggunakan teknik analisis multi kriteria AHP yang diintegrasikan dengan SIG. Berikut beberapa data yang dipersiapkan melalui penerapan teknologi SIG:

a. Peta Geologi Lembar Gunung Kelud skala 1 : 50.000;

b. Aster Global DEM resolusi spasial 30 meter, data tersebut digunakan untuk membuat indeks kemiringan lereng di lokasi penelitian; dan

c. Data curah hujan dalam kurun waktu periode selama 3 tahun terakhir (2014-2016), dasar data ini digunakan untuk menentukan ketersediaan air untuk kesesuaian lahan.

\section{Analisis Sampel Tanah Hasil Survei dan Laboratorium}

Sifat fisik dan kimia tanah di lokasi penelitian diidentifikasi melalui proses survei dan analisis laboratorium. Sifat fisik diidentifikasi melalui survei lapangan, beberapa informasi yang didapatkan terdiri dari nilai ketebalan erupsi, kedalaman tanah, batuan permukaan, singkapan dan kondisi drainase. Analisis laboratorium dilakukan untuk mendapatkan besaran nilai dari beberapa kriteria yang meliputi, tekstur tanah, KTK, pH, N total, P2O5, K2O dan C-organik.

\section{Penentuan Bobot Kriteria dengan AHP}

Pemberian nilai bobot dilakukan untuk setiap kriteria yang digunakan dalam analisis kesesuaian lahan (Meng et al., 2011). Nilai hasil bobot pada masing-masing kriteria dihasilkan melalui penerapan metode AHP (Malczewski, 1999; 2004). Penilaian preferensi ahli diterapkan dalam metode AHP. Penilaian ini merupakan inti dari metode AHP, karena akan berpengaruh terhadap prioritas elemen-elemen. Hasil dari penilaian ini disajikan dalam bentuk matriks pairwise comparison, yaitu matriks perbandingan berpasangan yang memuat tingkat preferensi pengambil keputusan terhadap alternatif berdasarkan kriteria-kriteria yang ada. Skala Saaty yang digunakan dalam proses preferensi ahli ditunjukkan oleh Tabel 1. Kemudian, masing-masing kriteria disusun dalam matriks perbandingan pairwise. Matriks perbandingan pairwise yang digunakan dalam analisis kesesuaian lahan pada penelitian ini ditunjukkan oleh Tabel 2.

Tabel 1. Skala Saaty Dalam Proses Preferensi Ahli

\begin{tabular}{cl}
\hline Tingkat Kepentingan & \multicolumn{1}{c}{ Definisi } \\
\hline 1 & Sama pentingnya dibanding yang lain \\
3 & Moderat pentingnya dibanding yang lain \\
5 & Kuat pentingnya dibanding yang lain \\
7 & Sangat kuat pentingnya dibanding yang lain \\
9 & Ekstrim pentingnya dibanding yang lain \\
$2,4,6,8$ & Nilai di antara dua penilaian yang berdekatan \\
\hline
\end{tabular}

Tabel 2. Matriks Perbandingan Pairwise Kesesuaian Lahan

\begin{tabular}{|c|c|c|c|c|c|c|c|c|c|c|c|c|c|c|c|}
\hline Sub-Kriteria & 1 & 2 & 3 & 4 & 5 & 6 & 7 & 8 & 9 & 10 & 11 & 12 & 13 & 14 & 15 \\
\hline Temperatur & 1 & $1 / 2$ & $1 / 3$ & $1 / 3$ & $1 / 2$ & $1 / 3$ & $1 / 3$ & $1 / 4$ & $1 / 3$ & $1 / 3$ & $1 / 3$ & $1 / 3$ & $1 / 2$ & $1 / 2$ & $1 / 2$ \\
\hline $\begin{array}{l}\text { Hujan } \\
\text { bulanan }\end{array}$ & 2 & 1 & $1 / 2$ & $1 / 3$ & $1 / 3$ & $1 / 3$ & $1 / 3$ & $1 / 4$ & $1 / 3$ & $1 / 3$ & $1 / 3$ & $1 / 3$ & $1 / 2$ & $1 / 2$ & $1 / 2$ \\
\hline Drainase & 3 & 2 & 1 & $1 / 3$ & 0,5 & $1 / 3$ & $1 / 3$ & $1 / 4$ & $1 / 3$ & $1 / 3$ & $1 / 3$ & $1 / 3$ & 2 & 2 & 2 \\
\hline $\begin{array}{l}\text { Tekstur } \\
\text { tanah }\end{array}$ & 3 & 3 & 3 & 1 & 3 & 2 & 2 & 1 & 2 & 2 & 2 & $1 / 3$ & 2 & 2 & 2 \\
\hline $\begin{array}{l}\text { Ketebalan } \\
\text { Erupsi }\end{array}$ & 2 & 3 & 2 & $1 / 3$ & 1 & $1 / 2$ & $1 / 2$ & $1 / 3$ & 2 & 2 & 2 & $1 / 3$ & 2 & 2 & 2 \\
\hline Kedalaman & 3 & 3 & 3 & $1 / 2$ & 2 & 1 & 2 & $1 / 3$ & 2 & 2 & 2 & $1 / 3$ & 2 & 2 & 2 \\
\hline KTK & 3 & 3 & 3 & $1 / 2$ & 2 & $1 / 2$ & 1 & $1 / 3$ & 2 & 2 & 2 & $1 / 3$ & 2 & 2 & 2 \\
\hline $\mathrm{pH}$ & 4 & 4 & 4 & 1 & 3 & 3 & 3 & 1 & 3 & 3 & 3 & $1 / 3$ & 2 & $1 / 2$ & $1 / 2$ \\
\hline N Total & 3 & 3 & 3 & $1 / 2$ & $1 / 2$ & $1 / 2$ & $1 / 2$ & $1 / 3$ & 1 & 1 & 1 & $1 / 3$ & $1 / 2$ & $1 / 2$ & $1 / 2$ \\
\hline $\mathrm{P}_{2} \mathrm{O}_{5}$ & 3 & 3 & 3 & $1 / 2$ & $1 / 2$ & $1 / 2$ & $1 / 2$ & $1 / 3$ & 1 & 1 & 1 & $1 / 3$ & $1 / 2$ & $1 / 2$ & $1 / 2$ \\
\hline $\mathrm{K}_{2} \mathrm{O}$ & 3 & 3 & 3 & $1 / 2$ & $1 / 2$ & $1 / 2$ & $1 / 2$ & $1 / 3$ & 1 & 1 & 1 & $1 / 3$ & $1 / 2$ & $1 / 2$ & $1 / 2$ \\
\hline Ekonomis & 3 & 3 & 3 & 3 & 3 & 3 & 3 & 3 & 3 & 3 & 3 & 1 & 4 & 3 & 3 \\
\hline Kemiringan & 2 & 2 & $1 / 2$ & $1 / 2$ & $1 / 2$ & $1 / 2$ & $1 / 2$ & $1 / 2$ & 2 & 2 & 2 & $1 / 3$ & 1 & 2 & $1 / 3$ \\
\hline Batuan & 2 & 2 & $1 / 2$ & $1 / 2$ & $1 / 2$ & $1 / 2$ & $1 / 2$ & 2 & 2 & 2 & 2 & $1 / 3$ & 0,5 & 1 & 1 \\
\hline Singkapan & 2 & 2 & $1 / 2$ & $1 / 2$ & $1 / 2$ & $1 / 2$ & $1 / 2$ & 2 & 2 & 2 & 2 & $1 / 3$ & 3 & 1 & 1 \\
\hline Jumlah & 39 & 37,5 & 30,3 & 10,3 & 18,3 & 14 & 15,5 & 12,3 & 24 & 24 & 24 & 5,67 & 23 & 20 & 18,3 \\
\hline
\end{tabular}


Estimasi konsistensi proses pembandingan yang dilakukan dengan menggunakan matriks pairwise comparison melalui penghitungan nilai maksimum principal eigenvector $\left(\lambda \lambda_{\max }\right)$. Semakin dekat nilai $\lambda \lambda$ max ke n, maka semakin konsisten hasil yang dicapai. Dalam AHP, nilai konsistensi dinyatakan dalam rasio konsistensi (consistency ratio/ CR), yang diperoleh melalui perhitungan indeks konsistensi (consistency index/CI) dan indeks random konsistensi (consistency random index/ RI). Nilai $\mathrm{CR}$ diperoleh dengan persamaan 1, sedangkan nilai $\mathrm{Ci}$ diperoleh dengan persamaan 2 .

$$
\begin{aligned}
& \mathrm{CR}=\frac{C I C I}{R I R I} \ldots \ldots \\
& \mathrm{CI}=\frac{\lambda-n \lambda-n}{n-1 n-1}
\end{aligned}
$$

Nilai RI merupakan nilai - nilai rata-rata indeks yang dihasilkan secara random dan diperoleh dari percobaan yang digunakan hingga 15. Nilai RI didapat dari pembagian nilai CI dengan nilai RI pada order matriks yang sepadan pada Tabel 3. Saaty (2004) menyebutkan bahwa untuk kepentingan evaluasi, CR dengan nilai 0.10 (atau 10\%) atau lebih kecil dianggap dapat diterima .

Tabel 3. Matriks Nilai RI

\begin{tabular}{|c|c|c|c|c|c|c|c|c|c|c|c|c|c|c|c|}
\hline $\begin{array}{c}\text { Order of } \\
\text { Matrix }\end{array}$ & 1 & 2 & 3 & 4 & 5 & 6 & 7 & 8 & 9 & 10 & 11 & 12 & 13 & 14 & 15 \\
\hline $\begin{array}{c}\text { Random } \\
\text { Index }\end{array}$ & 0 & 0 & 0,58 & 0,90 & 1,12 & 1,24 & 1,32 & 1,41 & 1,45 & 1,49 & 1,51 & 1,48 & 1,56 & 1,57 & 1,59 \\
\hline
\end{tabular}

Sumber: Saaty (2004)

\section{Visualisasi Informasi Kesesuaian Lahan}

Visualisasi kesesuaian lahan dilakukan dengan proses tumpang susun (overlay) masing-masing. Dalam penerapan penilaian multikriteria terdapat hubungan antara layer yang menjadi input dengan hasil proses overlay. Sebelum dilakukan proses overlay, masingmasing kriteria yang digunakan disajikan dalam bentuk informasi spasial. Visualisasi dari masing-masing kriteria disajikan pada Gambar 3. Tahapan overlay masing-masing layer input menggunakan tools yang disediakan oleh perangkat lunak ArcGIS. Hasil dari proses overlay akan menghasilkan informasi spasial berupa peta kesesuaian lahan lokasi penelitian.

\section{Persepsi Masyarakat Terhadap Kondisi Pertanian Pasca Erupsi Gunungapi Kelud}

Focused Group Discussion (FGD) dilakukan untuk mengetahui persepsi masyarakat terkait kondisi pertanian 3 tahun pasca erupsi Gunungapi Kelud. Tahapan wawancara FGD dilakukan di Desa Penataran, Kecamatan Nglegok, Kabupaten Kediri, di mana lokasi tersebut merupakan daerah terdampak langsung oleh material erupsi, serta kegiatan pertanian merupakan salah satu basis perekonomian masyarakat.



Gambar 3. Visualisasi masing-masing kriteria. (1) Presentase batuan dipermukaan, (2) Rata-rata curah hujan bulanan dalam 3 tahun, (4) kedalaman tanah,

(5) kelas drainase, (6) kemiringan, (7) ketebalan erupsi aktual, (8) nilai ekonomis lahan pertanian, (9) nilai K, (10) nilai KTK, (11) nilai N total, dan (12) nilai $\mathrm{P}$ 


\section{HASIL DAN PEMBAHASAN}

\section{Kesesuaian Lahan Pertanian}

Penentuan bobot pada masing-masing kriteria kesesuaian lahan pertanian merupakan tahap awal yang dilakukan. Penentuan nilai bobot masing-masing kriteria dihasilkan dari perhitungan dengan metode AHP (Malczewski, 2004). Hasil perhitungan AHP yang dilakukan menghasilkan nilai bobot dengan tingkat CR sebesar $=0,05$. Apabila nilai $\mathrm{CR}<0,1$, maka preferensi ahli yang dilakukan dan nilai bobot yang telah diperoleh dapat digunakan untuk proses analisis kesesuain lahan. Tabel 4 menunjukkan besaran bobot pada masingmasing kriteria yang digunakan.

Berdasarkan nilai bobot yang telah diperoleh, dapat diketahui seberapa besar pengaruh setiap kriteria terhadap kondisi analisis kesesuain lahan. Kriteria ekonomis menjadi parameter yang memiliki pengaruh besar dalam penilaian kesesuain lahan. Kriteria ekonomis terkait dengan kemampuan petani dalam pengolahan lahan pertanian yang terdapat di lokasi penelitian. Nilai pH menjadi kriteria dengan nilai bobot tertinggi, yang mewakili karakteristik sifat kimia tanah. Tekstur tanah menjadi kriteria yang memiliki bobot tertinggi yang mewakili sifat fisik tanah.

Penyajian informasi spasial kesesuaian lahan dilakukan dengan menerapkan metode overlay dengan mengintegrasikan hasil penilaian multikriteria menggunakan teknologi SIG. Selanjutnya, dilakukan klasifikasi kesesuaian lahan ke dalam kelas-kelas kesesuaian. Menurut FAO (1984; 1986; dan 2007), tingkat kesesuaian lahan dapat dibagi ke dalam kelas S1 (sangat sesuai), S2 (sesuai sedang), S3 (marginal sesuai), dan N (tidak sesuai). Tahap terakhir adalah layouting informasi yang diperoleh menjadi peta kesesuaian lahan di lokasi penelitian. Peta kesesuaian lahan di lokasi penelitian disajikan dalam Gambar 4.

Hasil pemetaan diperoleh luasan untuk masingmasing kelas kesesuaian lahan. Pada kelas kesesuaian S1, terdapat luas area sebesar 15594,47812 Ha dengan persentase 64,74\%. Kelas kesesuaian S2 memiliki luas area sebesar 7589,133569 $\mathrm{Ha}$, dengan persentase 31,51\%. Luas area kelas kesesuaian lahan S3 sebesar $903,687912 \mathrm{Ha}$, dengan persentase $3,75 \%$. Tabel 5 menunjukkan luasan dan persentase pada masingmasing kelas kesesuaian lahan.

Melalui informasi di atas, dapat diketahui bahwa kondisi lahan pasca erupsi Gunungapi Kelud tahun 2014 memiliki potensi untuk mendukung aktivitas pertanian. Berdasarkan informasi yang dihasilkan, dapat menjadi input dalam penentuan dan pengambilan keputusan dalam menata kawasan pertanian di lokasi penelitian. Dilakukannya proses penataan tersebut dapat mendorong produktifitas komoditas pertanian menjadi lebih maksimal.

Tabel 4. Pembobotan pada Masing Masing Kriteria

\begin{tabular}{cc}
\hline Kriteria & Bobot AHP \\
\hline Temperatur & 0,02 \\
Hujan bulanan & 0,03 \\
Drainase & 0,05 \\
Tekstur tanah & 0,11 \\
Ketebalan Erupsi & 0,07 \\
Kedalaman & 0,1 \\
KTK & 0,09 \\
pH & 0,13 \\
$\mathrm{~N}_{\text {Total }}$ & 0,06 \\
$\mathrm{P}_{2} \mathrm{O}_{5}$ & 0,06 \\
$\mathrm{~K}_{2} \mathrm{O}$ & 0,06 \\
Ekonomis & 0,17 \\
Kemiringan & 0,05 \\
Batuan & 0,06 \\
Singkapan & 0,07 \\
\hline
\end{tabular}




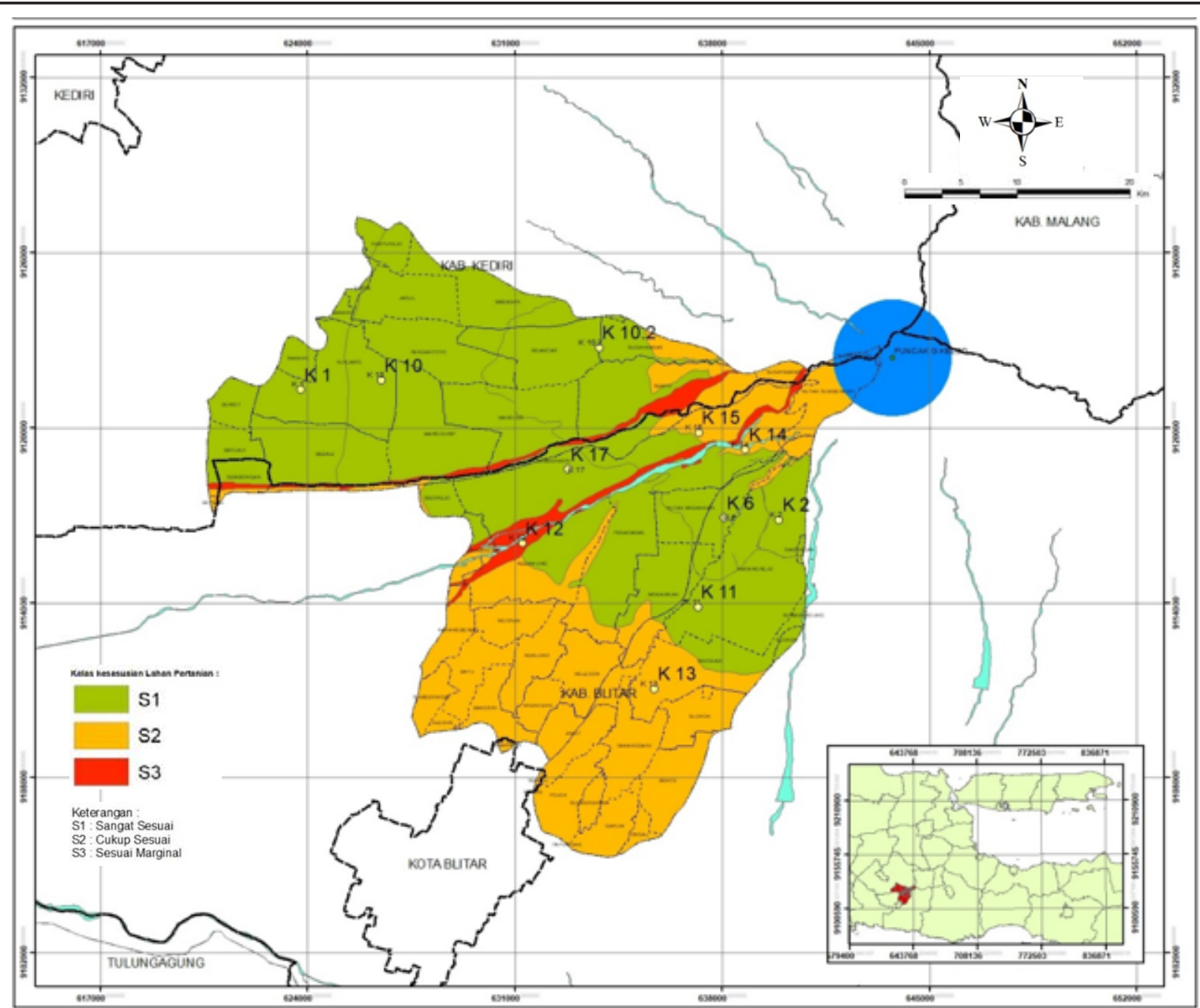

Gambar 4. Peta Kesesuaian Lahan Lokasi Penelitian

Tabel 4. Luasan Masing-masing Kelas Kesesuaian Lahan

\begin{tabular}{ccc}
\hline Kelas & Luas $(\mathrm{Ha})$ & $(\%)$ \\
\hline S1 & 15594,47812 & 64,74 \\
S2 & 7589,133569 & 31,51 \\
S3 & 903,687912 & 3,75 \\
Jumlah & 24087,2996 & 100 \\
\hline
\end{tabular}

Sumber: Hasil Analisis Data

\section{Potensi Kesuburan Tanah}

Material erupsi, khususnya abu vulkanik memiliki potensi untuk meningkatkan kesuburan tanah. Penaksiran kondisi kesuburan tanah dilakukan dengan identifikasi sifat kimia tanah berupa kadar $\mathrm{pH}$, KTK, C-Organik, N total, P2O5, K2O. Berdasarkan pada Tabel 5, diketahui nilai untuk masing-masing sifat kimia yang digunakan dalam penelitian ini.

Tingkat keasaman dan kebasaan tanah ditentukan oleh besarnya nilai pH. Hasil uji laboratorium menunjukkan bahwa besaran $\mathrm{pH}$ adalah 6,4. Kondisi pH dengan rentang nilai antara 6-7 sangat baik untuk mendukung tumbuh suatu tanaman (Lebon, 2009). Kandungan unsur makro N, P dan K menjadi faktor yang menentukan tingkat ketersediaan hara di dalam tanah (Shoji \& Takahashi, 2002). Berdasarkan hasil di atas, diketahui nilai P2O5 sangat tinggi. Analisis kandungan kimia tanah menjadi penting untuk mengetahui tingkat kesuburan dan daya dukung lahan terhadap aktivitas pertanian. 


\begin{tabular}{cccc}
\hline \multicolumn{4}{c}{ Tabel 5. Nilai Sifat Kimia } \\
\hline Parameter & Unsur Hara & Satuan & Rata-rata Hasil \\
\hline Retensi Hara & $\mathrm{pH}\left(\mathrm{H}_{2} \mathrm{O}\right)$ & & 6,4 \\
& $\mathrm{KTK}$ & $\mathrm{me} / 100 \mathrm{gr}$ & 9,21 \\
& $\mathrm{C}-$ Organik & $\%$ & 0,13 \\
Ketersediaan Hara & $\mathrm{N}$ total & $\%$ & 0,15 \\
& $\mathrm{P}_{2} \mathrm{O}_{5}$ & $\mathrm{ppm}$ & 76,4 \\
& $\mathrm{~K}_{2} \mathrm{O}$ & $\mathrm{mg} / 100 \mathrm{gr}$ & 0,37 \\
\hline
\end{tabular}

Sumber: Hasil Analisis Data

\section{Perkembangan Pertanian Pasca Erupsi Gunungapi Kelud 2014}

Kondisi pertanian pasca erupsi Gunungapi Kelud tahun 2014 mengalami perkembangan yang pesat. Hasil survei menunjukkan bahwa lahan pertanian terdampak erupsi telah sepenuhnya digunakan untuk bercocok tanam kembali, kecuali kawasan yang berada di sekitar aliran lahar. Berdasarkan hasil survei didperoleh informasi bahwa perkebunan nanas (Gambar 5) menyebar luas dan mendominasi di Kecamatan Gandusari, Kecamatan Garum, Kecamatan Nglegok Kabupaten Blitar hingga Kecamatan Ngancar Kabupaten Kediri. Keadaan tersebut mendorong masyarakat setempat memberikan nama daerah tersebut dengan sebutan "Kampung Nanas". Tidak hanya itu, Kecamatan Ngancar sempat membuat Festival Nanas pada oktober 2016 untuk memperkenalkan tanaman ini menjadi "ikon" Kecamatan Ngancar. Selain itu, penduduk sekitar juga menamai nanas di daerah ini dengan sebutan "nanas queen". Hal ini disebabkan luas lahan tanaman ini dikecamatan Ngancar lebih dari 2.500 hektar dengan kapasitas produksi hingga 50 ton/ hektar.

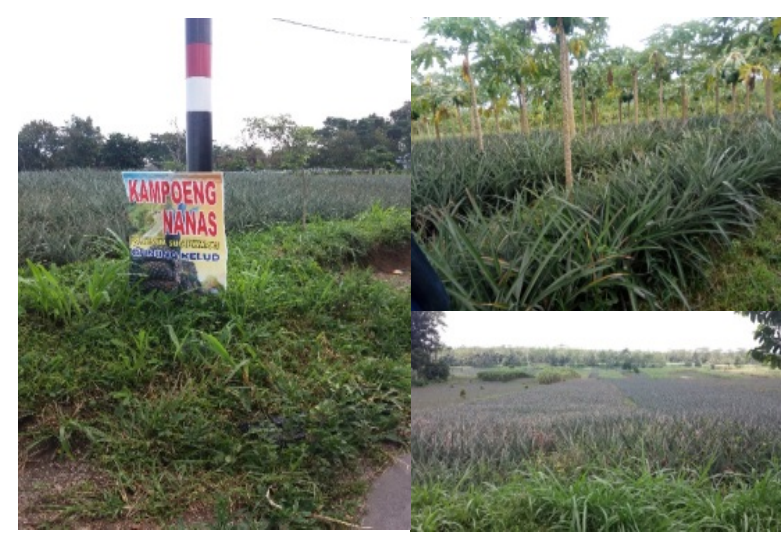

Gambar 5. Komoditas Nanas di Lokasi Penelitian
Produksi sub sektor tanaman bahan makanan juga mengalami pertumbuhan jika dibandingkan dengan tahun 2013 yaitu 4,87\%. Kemudian hasil agribisnis/ produksi pertanian pada setiap sektor pertanian tahun 2014 mengalami peningkatan melebihi target yang ditentukan pemerintah, kecuali pada tanaman manggis yang mengalami penurunan produktivitas seperti terlihat pada grafik pada Gambar 6.

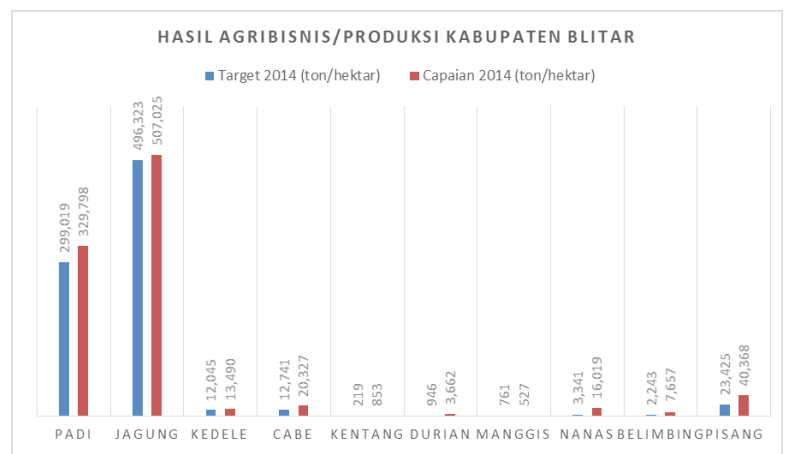

Gambar 6. Hasil Agribisnis Produksi Kabupaten Blitar

Perkembangan sektor pertanian pasca erupsi ditunjukkan dengan munculnya destinasi agrowisata. Destinasi tersebut di antaranya Perkebunan Gambar dengan sektor unggulannya berupa pepaya jenis taiwan dan nanas, Kampung Anggrek dengan komoditas unggulannya berupa koleksi tanaman bunga anggrek, Kebun Kopi dengan komoditas unggulannya adalah produk-produk hasil olahan kopi, dan taman bunga sebagai salah satu atraksi wisatanya. Selain itu terdapat Kampung melon dengan komoditas unggulannya berupa buah melon dengan kualitas baik, Perkebunan Margomulyo dengan sektor unggulan berupa buah nanas dengan rasa yang sangat manis, stroberi dan alpukat. Tabel 6 dan Gambar 7 menunjukkan beberapa destinasi agrowisata di kawasan Gunungapi Kelud pasca erupsi tahun 2014. 
Tabel 6. Lokasi Destinasi Agrowisata di Kawasan Gunungapi Kelud

\begin{tabular}{cl}
\hline Destinasi Agrowisata & \multicolumn{1}{c}{ Alamat } \\
\hline Kebun Kopi Karanganyar & Ds. Modangan, Nglegok, Blitar \\
Kampung Melon & Ds. Modangan, Nglegok, Blitar \\
Kampung Anggrek & Ds. Sempu, Ngancar, Kediri \\
Kampung Nanas & Ds. Sempu, Ngancar, Kediri \\
Taman Bunga Margomulyo & Ds. Sugihwaras, Ngancar, Kediri \\
\hline
\end{tabular}

Sumber: Hasil Inventarisasi Survei Lapangan
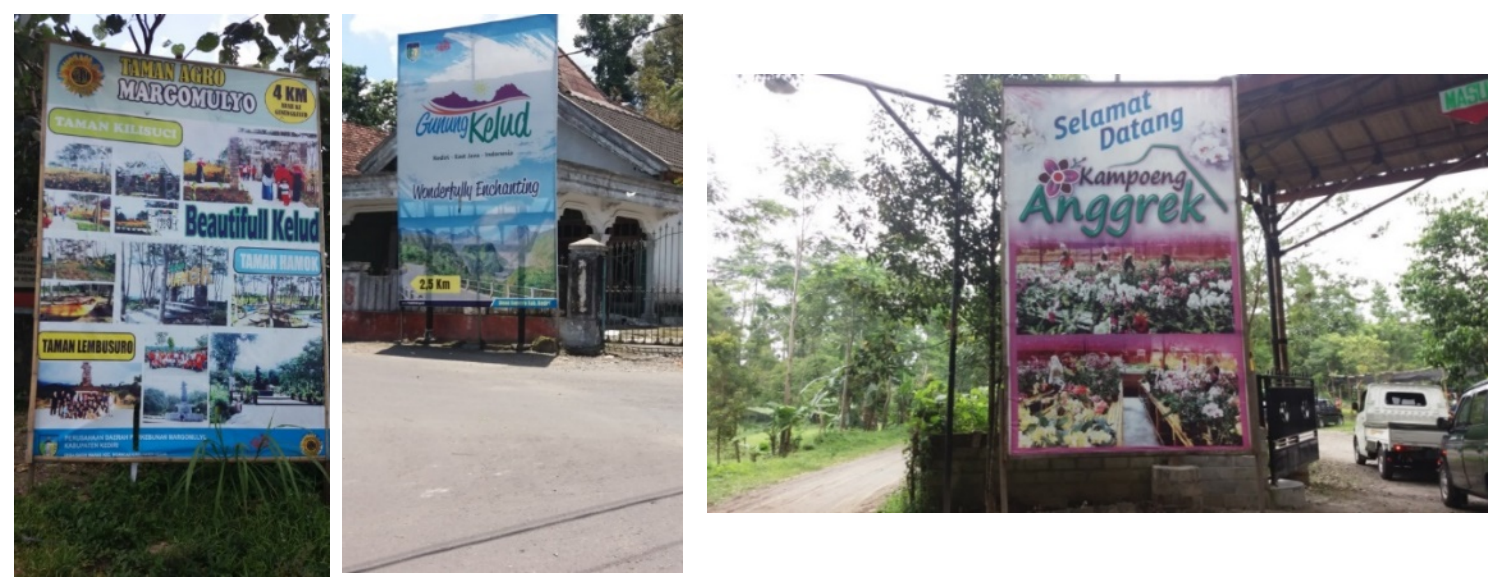

Gambar 7. Beberapa Destinasi Agrowisata di Kawasan Gunungapi Kelud

\section{Persepsi Masyarakat}

Upaya untuk mengetahui persepsi masyarakat dilakukan dengan mengadakan FGD. Identifikasi persepsi tersebut dilakukan untuk mendapatkan informasi terkait bagaimana sudut pandang masyarakat terhadap fenomena erupsi Gunungapi Kelud. Dalam forum FGD yang dilaksanakan diundang beberapa perwakilan masyarakat yang terdiri dari kelompok tani, pemerintah (dalam hal ini pihak pemerintah desa dan BPBD), dan pelaku pariwisata di lokasi penelitian.



Gambar 9. Focused Discussion Group (FGD)

Informasi terkait dengan persepsi masyarakat menjadi sangat penting dalam penelitian ini. Informasi didapatkan melalui FGD dengan masyarakat. Berdasarkan FGD yang telah dilakukan, didapatkan persepsi dan sudut pandang masyarakat terkait dengan dampak erupsi Gunungapi Kelud pada tahun 2014. Semua perwakilan masyarakat sepakat bahwa erupsi Gunungapi Kelud membawa dampak positif, terutama bagi aktivitas pertanian. Mereka menyadari bahwa terdapat dampak negatif yang sangat besar, namun itu hanya dirasakan pada kurun waktu jangka pendek. Faktanya, terjadi peningkatan produktifitas pertanian karenakan semakin tingginya kesuburan tanah, yang kemudian semakin berkembangnya sektor pertanian berbasis agrowisata menjadi dampak positif yang dirasakan secara berkelanjutan. Hal tersebut berimplikasi langsung terhadap peningkatan perekonomian masyarakat di kawasan Gunungapi Kelud.

\section{KESIMPULAN}

Dampak erupsi Gunungapi Kelud memiliki dampak yang besar terhadap peningkatan kualitas lahan, khususnya untuk mendukung aktivitas pertanian. Penerapan analisis kesesuian lahan berbasis penilaian multikriteria yang diintegrasikan dengan teknologi SIG menghasilkan informasi yang sangat berguna sebagai upaya optimalisasi lahan terdampak erupsi. Selain itu, analisis sifat kimia tanah dilakukan untuk mengetahui kandungan hara yang menjadi informasi penting 
terkait dengan tingkat kesuburan dan daya dukung lahan untuk kawasan pertanian juga sangat membantu akurasi dari penilaian AHP. Hasil dari seluruh proses penelitian didapatkan bahwa erupsi Gunungapi Kelud membawa dampak positif bagi aktivitas pertanian dan pengembangannya, serta berimplikasi terhadap peningkatan perekonomian masyarakat.

\section{UCAPAN TERIMA KASIH}

Terimakasih diucapkan kepada Kemenristek Dikti yang telah membiayai penelitian ini melalui dana hibah skema PUPT.

\section{DAFTAR PUSTAKA}

Achmad, S. R., \& Hadi, H. (2015). Identifikasi Sifat Kimia Abu Vulkanik Dan Upaya Pemulihan Tanaman Karet Terdampak Letusan Gunung Kelud (Studi Kasus: Kebun Ngrangkah Pawon, Jawa Timur). Warta Perkaretan, 34(1), 19-30.

Afandi, F. N., Siswanto, B., \& Nuraini, Y. (2017). Pengaruh Pemberian Berbagai Jenis Bahan Organik Terhadap Sifat Kimia Tanah Pada Pertumbuhan Dan Produksi Tanaman Ubi Jalar Di Entisol Ngrangkah Pawon, Kediri. Jurnal Tanah Dan Sumberdaya Lahan, 2(2), 237-244

Akıncı, H., Özalp, A. Y., \& Turgut, B. (2013). Agricultural land use suitability analysis using GIS and AHP technique. Computers and Electronics in Agriculture, 97, 71-82.

Al-Mashreki, M. H., Akhir, J. B. M., Rahim, S. A., Lihan, K., \& Haider, A. R. (2011). GIS-based sensitivity analysis of multi-criteria weights for land suitability evaluation of sorghum crop in the Ibb Governorate Republic of Yemen. Journal of Basic and Applied Scientific Research, 1(9), 1102-1111.

Bachri, S., Stötter, J., Monreal, M., \& Sartohadi, J. (2015). The calamity of eruptions, or an eruption of benefits? Mt. Bromo human-volcano system a case study of an open-risk perception. Natural Hazards and Earth System Science, 15(2), 277290.

Blake, D., \& GNS Science (N.Z.). (2015). The 2014 eruption of Kelud Volcano, Indonesia: impacts on infrastructure, utilities, agriculture and health.

Ceballos-Silva, A., \& López-Blanco, J. (2003). Delineation of suitable areas for crops using a Multi-Criteria Evaluation approach and land use/ cover mapping: a case study in Central Mexico. Agricultural Systems, 77(2), 117-136.

Collins, M. G., Steiner, F. R., \& Rushman, M. J. (2001). Land-Use Suitability Analysis in the United States: Historical Development and Promising Technological Achievements. Environmental Management, 28(5), 611-621.
Dahlgren, R. A., Saigusa, M., \& Ugolini, F. C. (2004). The Nature, Properties and Management of Volcanic Soils. In Advances in Agronomy (Vol. 82, pp. 113-182). Elsevier.

Ebrahim, E., \& Mohamed, A. (2017). A GIS based land suitability analysis for sustainable agricultural planning in Gelda catchment, Northwest Highlands of Ethiopia. Journal of Geography and Regional Planning, 10(5), 77-91.

Eswaran, H., Van Den Berg, E., \& Reich, P. (1993). Organic carbon in soils of the world. Soil Science Society of America Journal, 57(1), 192-194.

FAO. (1984). Land evaluation. Part III: Crop environmental requirements; Technical report 5. Retrieved July 18, 2017, from http://www.fao.org/ docrep/018/t0412e/t0412e.pdf

FAO. (1986). Ethiopian Highlands Reclamation Study: Ethiopia. Retrieved July 18, 2017, from http:// www.fao.org/docrep/field/009/ar863e/ar863e.pdf

FAO. (2007). Land Evaluation: towards a Revised Framework. Retrieved July 18, 2017, from http:// www.fao.org/3/a-a1080e.pdf

Feizizadeh, B., \& Blaschke, T. (2013). Land suitability analysis for Tabriz County, Iran: a multi-criteria evaluation approach using GIS. Journal of Environmental Planning and Management, 56(1), $1-23$.

Himayah, S., Hartono, \& Danoedoro, P. 2017. Pemanfaatan Citra Landsat 8 Multitemporal dan Model Forest Canopy Density (FCD) untuk Analisis Perubahan Kerapatan Kanopi Hutan di Kawasan Gunung Kelud Jawa Timur. Majalah Geografi Indonesia, 31(1), 65 - 72.

Kalogirou, S. (2002). Expert systems and GIS: an application of land suitability evaluation. Computers, Environment and Urban Systems, 26(2), 89-112

Lebon, S. L. (2009). Volcanic activity and environment. Impacts on agriculture and use of geological data to improve recovery processes. Retrieved from http:// skemman.is/stream/get/1946/3303/10384/1/ Sylviane_Lebon_fixed.pdfJun

Malczewski, J. (1999). GIS and multicriteria decision analysis. John Wiley \& Sons. Retrieved from https://books.google.com/books?hl=id\&lr=\&id= 2Zd54x4_2Z8C\&oi=fnd\&pg=PR1\&dq=spatial+ multi+criteria + malczewski\&ots $=$ FI4nJOQK3W \&sig=lwYJ6L8Be8vGJ_x_rBK6jireDOY

Malczewski, J. (2004). GIS-based land-use suitability analysis: a critical overview. Progress in Planning, 62(1), 3-65. https://doi.org/10.1016/j. progress.2003.09.002

Meng, Y., Malczewski, J., \& Boroushaki, S. (2011). A GIS-Based Multicriteria Decision Analysis Approach for Mapping Accessibility Patterns 
of Housing Development Sites: A Case Study in Canmore, Alberta. Journal of Geographic Information System, 03(01), 50-61. https://doi. org/10.4236/jgis.2011.31004

Prakash, T. N. (2003). Land suitability analysis for agricultural crops: a fuzzy multicriteria decision making approach. International Institute for Geo-Information Science and Earth Observation, Enschede, The Netherlands. Retrieved from http://www.itc.nl/library/Papers_2003/msc/gfm/ prakash.pdf.

Purnamasari, A.N.C., Sartohadi, J. \& Wahyudi. (2015). Perhitungan Volume dan Karakterisasi Material Endapan Erupsi Gunungapi Kelud Tahun 2014 di Sungai Bladak Bagian Hulu dengan Metode Geofisika. Majalah Geografi Indonesia, 29(2), 111 $-116$.

Reshmidevi, T. V., Eldho, T. I., \& Jana, R. (2009). A GIS-integrated fuzzy rule-based inference system for land suitability evaluation in agricultural watersheds. Agricultural Systems, 101(1), 101109.

Saaty, T. L. (2004). Decision making - the Analytic Hierarchy and Network Processes (AHP/ ANP). Journal of Systems Science and Systems Engineering, 13(1), 1-35.

Shoji, S., \& Takahashi, T. (2002). Environmental and agricultural significance of volcanic ash soils. GLOBAL ENVIRONMENTAL RESEARCHENGLISH EDITION-, 6(2), 113-135.

Thapa, R. B., \& Murayama, Y. (2008). Land evaluation for peri-urban agriculture using analytical hierarchical process and geographic information system techniques: A case study of Hanoi. Land Use Policy, 25(2), 225-239.

Wardhana, G. M. K., Maritimo, F., Maulana, E., \& Ammarullah, A. (2014). PemetaanDaerah-Rawan-Jatuhan-Material-PiroklastikKasus-Erupsi-Gunungapi-Kelud-2014.pdf. Retrieved July 17, 2017, from https://www. researchgate.net/profile/Edwin_Maulana2/ publication/303967643_Pemetaan_Daerah_ Rawan_Jatuhan_Material_Piroklastik_ Kasus_Erupsi_Gunungapi_Kelud_2014/ links/5760b55308ae244d0370d399/PemetaanDaerah-Rawan-Jatuhan-Material-PiroklastikKasus-Erupsi-Gunungapi-Kelud-2014.pdf 